\title{
Business English talent cultivation research under the background of regional cross-border electricity
}

\author{
Yu Huijun \\ Jiangxi Teachers College, Yingtan, Jiangxi, 335000, China
}

Keywords: Cultivation of talents; Cross-border electricity; Business English

\begin{abstract}
The meteoric rise of cross-border e-commerce has become one of the pillars of our foreign trade. Survey found that heavy cross-border e-commerce booming had a large demand for relevant personnel. We think, for the regional economic development, efforts should be made to break through the backstage that the talent cultivation target is not clear; university-enterprise cooperation is not deep. Through clearly positioning the talents training goal, refining the personnel specification, systematization and institutionalization of practice teaching mode, we rebuild the cross-border electricity industry demand docking mode of talent training, and achieved professional and the rapid development of the enterprise. Current business English professional is beginning to exist as an independent subject, and formulating the business English talent training mode to meet the requirements of social development is particularly important. In this article, through the analysis of the talent demand, we explored the social expectation and outlook on talents, and we want to establish a talent cultivation system that can meet the demands of social development, and do services for social economic development.
\end{abstract}

\section{Introduction}

Higher vocational education is an important part of higher education, which is committed to highly skilled, applied talents cultivation, and has obvious attributes of vocational schooling, and which requires personnel training goal and the market requirements[2]. Under the background of the era of "Internet", cross-border electricity business is booming, and it has become a new growth point of China's foreign trade import and export of development. In 2016 China's cross-border electricity trading size increased from 2008 to 0.8 trillion yuan to 6.5 trillion yuan, accounting for $19 \%$ of the whole foreign trade scale, average annual growth of nearly $30 \%$. In the face of the current economic new normal, it is necessary for business English major, can also be worthwhile to re-examine its personnel training mode, to adapt to and service the needs of the regional economic development.With the deepening of China's reform and opening, business English has can exist as a mature, independent discipline, it also means business English majors must have their own talent training scheme[5]. In this paper, the research will be based on the investigation of unit of choose and employ persons, discuss business English talent demand situation in guangzhou, in order to make more in line with the social development need, comply with the requirement of unit of choose and employ persons, and accord with the characteristics of students' personality and talent training pattern to provide reliable basis for theory and practice, as well as improve the direction of business English curriculum system provides the basis.

Because of its convenient, fast and can meet the personalized requirements and characteristics of the price advantage, in recent years, the cross-border electricity sales are booming, gradually become one of the main ways of international trade.China electronic commerce research center monitoring data show that in the first half of 2015, China's cross-border electricity business turnover reached 2 trillion yuan, rose $42.8 \%$ of China's import and export gross $17.3 \%$. Guangdong as the provenance of China's reform and opening up policy, the open economy's achievement has attracted worldwide attention.Guangdong foreign trade import and export gross 2015 6. 36 trillion yuan, accounting for the same period of the total cost of the national foreign trade 25. 9\%. With cross-border e-commerce import and export, among them 167. 300 million yuan, the growth of 3.6 times, scale ranks the first place.Export electrical business software service providers and the rabbit, the reference technology 
based on platform partners, logistics providers launched "2015 China's exports of cross-border electricity industry research report [11], according to a report of guangdong province is China's cross-border electricity sellers most populous provinces, more than half of the sellers gathered here, at the same time, shenzhen, guangzhou respectively in the country's largest city of the first and the second to the seller.In January 2016, cross-border electricity business import and export of guangdong province 15. 400 million yuan, rose 13. 5 times[9]. Cross-border e-commerce industry association of guangdong province, head of forecast: the future cross-border electricity will be rapid development, by 2025, guangdong province, cross-border electricity volume will increase by more than $20 \%$ per year.

\section{The business English talent status}

Higher vocational business English has been committed to the professional training that can meet the need of international business line, has the good professional quality, strong English communication skills, familiar with the basic theoretical knowledge of international business and the business process of high-end skilled English talents, in order to promote the development of foreign trade in our country has trained a large number of talents. However, with the rise of cross-border electricity based on cross-border electricity business talents training is still in the exploratory stage. At present, compared with the electronic commerce, marketing, international trade major, business, for English major students, though they have advantage of that enterprises pay attention to the English language, but the general lack of cross-border electric business platform operation, marketing and promotion of knowledge and skills, it is difficult to adapt to cross-border electricity under the background of enterprise demand for talent diversification, points out. Investigate its reason, mainly has the following several aspects:

\subsection{Talents training goal is not clear}

Cross-border electrical business is a result of the rapid development of modern society, the diversity of the needs of the industry of talent.Because our country's cross-border electricity industry development time is shorter, colleges and universities in teaching and learning practice cross-border electricity shortage.Cultivation ways are usually "business English + business skills" or under the electronic commerce system for foreign language talents cultivation, unable to distinguish between cross-border e-commerce jobs in technical, business, integrated management of the different requirements of different positions of talent, for business English class talent into cross-border electricity producers will choose what industry jobs, what practical difficulties faced, higher vocational teachers tend to lack enough understanding.Training target is not clearly led to in the process of talent training, unable to learn information combined with practical work in the future.Lack of inexpensive and targeted teaching target, also can't provide the right talent for cross-border electricity industry.

\subsection{Specialty construction is relatively closed}

In order to cultivate the students' vocational skills and conscientiously to achieve the optimal allocation of resources, promoting the construction of professional group of fusion has been calling for higher vocational colleges and university-enterprise cooperation, however, is just slogans and form the cooperation and integration.First, in terms of university-enterprise cooperation, the Chinese cross-border electricity traders to study report display (see figure 1): only $3 \%$ of cross-border electricity enterprises hope that training is a school. This illustrates an embarrassing status: companies don't believe in university training. This from a side really reflects years advocated by the cooperation between colleges and the way out.Second, higher vocational colleges in the construction of the professional group of fusion, common among professional performance for "fragmented" relatively closed state, on the concept of education basic still confined to the traditional single professional training mode, between different professionals in curriculum setting, teaching staff and facilities equipped with limited within the scope of this major, and the lack of personnel exchange between professional, resource sharing and collaboration, difficult to play to the allocation of resources and talent cultivation process aspects of the advantage of professional work together more. This kind of condition can not adapt to the education demand, the change of external environment and 
diversity also can not adapt to the difference of the education object and requirements of individual all-round development, but also not conducive to business English professional build a cross major, teachers in a wide range of areas.Social and economic development needs to have a sustainable development of the professional ability of high-end skilled, marketization and modernization of English talents, how to break the boundaries and provide a platform, cultivating talents is really suitable for regional economic development business must think about the problem of business English major reform.

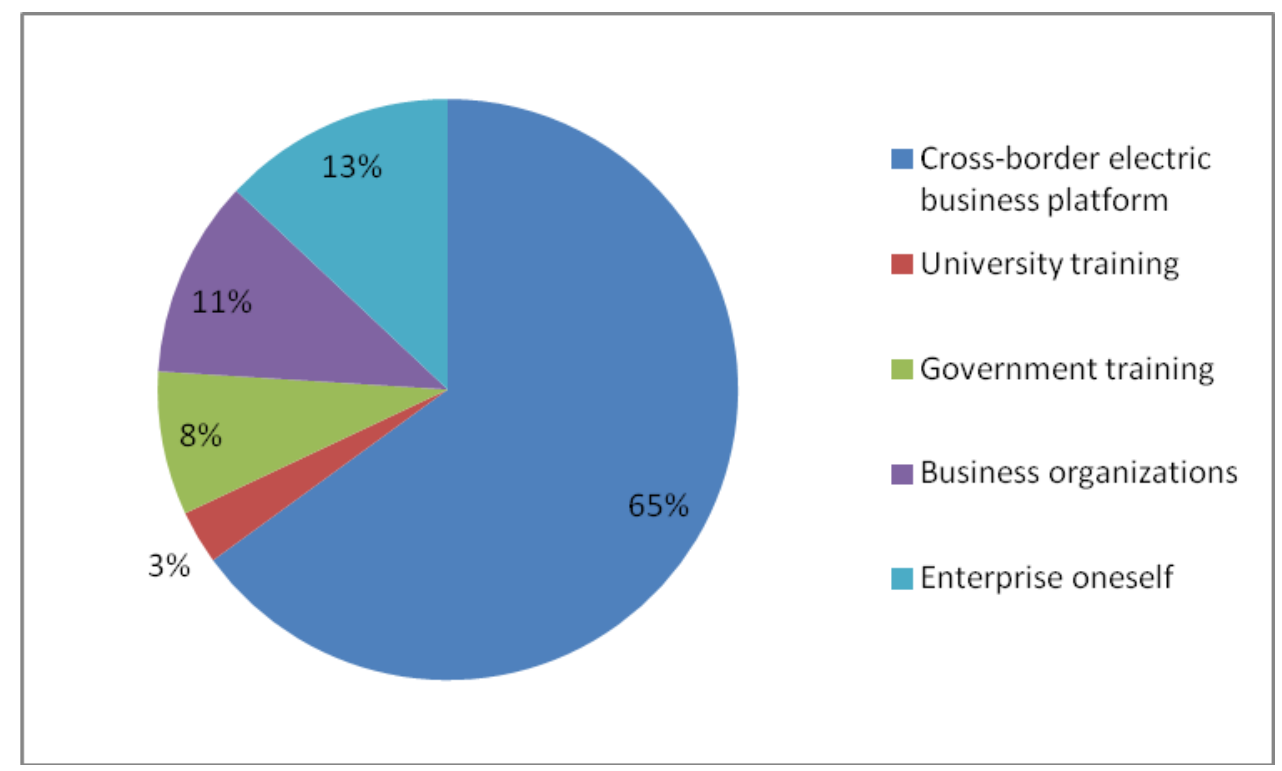

Figure.1 The way of training that people hope

\subsection{Partial evaluation system}

Teaching evaluation is based on a precise evaluation index, the quality of personnel training process and make objective and scientific evaluation and judgment.As an important link to the process of talent training, teaching evaluation is an effective form of inspection personnel training effect, also is the important means to motivate the teachers and students. Through different forms of evaluation, we can fully reflect the "teaching" and "learning" in the whole performance in the learning process, verify whether the teaching goals and achieve the desired learning effect.At the same time, all kinds of evaluation results timely feedback and will provide teachers and students in the subsequent adjustment to provide additional references in the learning process, and thus play a role of the construction of evaluation.However, because of various subjective and objective reasons, most of the talent training quality evaluation system of vocational colleges is not perfect, has not been able to establish a set of diagnostic, incentives, guidance and improve the evaluation mechanism.

Talent training quality evaluation system mainly includes the "evaluation of teaching" and "evaluation of learning" two aspects. In terms of "evaluation of teaching", it will be unable to do comprehensive and real. Most of the current vocational colleges carry out the students' evaluation of teaching approach, however, it tends to student's personal interest and the short-term effect, it is difficult to ensure fairness to the teachers' teaching process and teaching effect evaluation, such as some" speech "teachers tend to be very popular, and" thinking type "teachers often get low. In terms of "evaluation", is still given priority to for summative assessment. Summative evaluation is too much emphasis on evaluation of the screening and selection function, because the teaching evaluation functions of migration, ignoring the student's way of thinking and the ability to practice and training.

\section{Research design and research results}

\subsection{Research design}

The first part is the questionnaire design. This questionnaire is mainly investigated social or unit of choose and employ persons business English direction of a university in guangzhou, the level of student evaluation and understanding of business English talent and expectations. Questionnaire is 
made up of 35 items, divided into three parts, the first part is the basic condition of the respondents, such as unit properties, size, etc. The second part is the unit of choose and employ persons to student's evaluation, including 11-16 is on students' professional level and the comprehensive quality evaluation and expectation; The third part is the unit of choose and employ persons understanding of business English talent and expectations, including 17-19 and 20 to 24, respectively, to investigate the social understanding of business English talent and expectations of 25 to 31 of unit of choose and employ persons for business English talent demand situation.This article will focus on the second and the third part of the questionnaire. The survey, a total of 80 questionnaires, 68 valid questionnaires taken back.Questionnaire investigation object is this professional student internship units or graduate work units, mainly from the guangzhou region is engaged in the foreign trade of foreign companies, state-owned enterprises and private companies, most belong to more than medium-sized enterprises. Students opportunities to use English in these units are more frequently, most people are in the business or clerical work of the office.

\subsection{Research results analysis}

\subsubsection{The evaluation of company}

Seen from table 1, the vast majority of the units are satisfied with our graduates, this shows that the social recognition of horizontal direction of business English students, at the same time also give individual ability of the students, knowledge structure and performance can satisfy the basic requirement of unit of choose and employ persons.

Table.1 Company evaluation for the students

\begin{tabular}{|l|l|l|l|l|}
\hline Very satisfied & Satisfied & Regularly satisfied & Not satisfied & Not satisfied \\
\hline $25 \%$ & $47 \%$ & $28 \%$ & $0 \%$ & $6.8 \%$ \\
\hline
\end{tabular}

Questionnaire item 13 and 15 investigation unit of choose and employ persons to the evaluation of students' professional level, respectively (see table 2) and students need to improve or improvement." A good knowledge of English and have certain knowledge of business", "English writing ability strong" and "high" English power of expression in the top three, respectively;And students need to improve or improve respectively is "business field capacity (75\%)", "business theory knowledge (51.4\%)" and "English language skills (51.4\%). On the one hand, shows that students have with solid English language skills and basic business knowledge recognised by unit of choose and employ persons; But on the other hand also shows that unit of choose and employ persons to the direction of business English students have higher requirements, our students must further strengthen and improve in these aspects, in order to meet the needs of social and economic development.This group of data also shows that social for this kind of teaching mode of "English + business" for sure, at the same time, on another level to work for our future teaching brings revelation.

Table.2 Company Professional level evaluation for the students

\begin{tabular}{|l|l|l|l|l|}
\hline $\begin{array}{l}\text { A good knowledge of } \\
\text { English and business }\end{array}$ & $\begin{array}{l}\text { Good English } \\
\text { writing ability }\end{array}$ & $\begin{array}{l}\text { Good En } \\
\text { expression ability }\end{array}$ & Broad scope & $\begin{array}{l}\text { High level of } \\
\text { english-chinese } \\
\text { translation }\end{array}$ \\
\hline $60.2 \%$ & $53 \%$ & $42.6 \%$ & $25 \%$ & $20.6 \%$ \\
\hline
\end{tabular}

Table 3 shows that in terms of overall quality, unit of choose and employ persons think that most students with "team spirit", followed by "serious and responsible work", "accept ability strong" and "proactive"; Indicate that the direction to improve the students' comprehensive quality has a comprehensive, not only learned how to do things in their work, more learned the personhood, flexible in work performance, resourceful, at the same time also shows that we are "applied" business English talents training target to achieve in a certain extent.But "can bear" (13\%) of students rarely, while more than $52.9 \%$ of the respondents said "bear hardships and stand hard work spirit" is one aspect of the need to strengthen the students, in fact, this is "80 after" child general lack of ability, in the process of their growth, all rely on their parents and teachers, some students showed compressive ability in work. 
Table.3 The most outstanding quality the company thinks students have

\begin{tabular}{|l|l|l|l|l|}
\hline Cooperation spirit & $\begin{array}{l}\text { Work Seriously and } \\
\text { responsibly }\end{array}$ & High ability to accept & Work positively & Work hard \\
\hline $57.3 \%$ & $53 \%$ & $50 \%$ & $48.5 \%$ & $13 \%$ \\
\hline
\end{tabular}

\section{Summary}

From the point of our investigation, although the social direction of the current business English students' professional level and ability has a good evaluation, it provides us with the following enlightenment:

1) To develop a compound model of teachers team. To cultivate students must build a complex compound teachers, the disciplines of knowledge learning and the organic combination of language learning, help students to learn discipline system and the internal logic of knowledge, learn to use appropriate language to express this kind of knowledge and the internal logic, in order to improve the teaching level of teachers and improve teachers' scientific research level. It is a long-term task. But also meet the needs of the development of the era and their own.

2) To strengthen the teaching management. To cultivate highly qualified business English talents, there must be corresponding training measures, not only to formulate conforms to the social needs of the talent training scheme, and necessary in the teaching material, teaching method and teaching mode to further improvement, introduce advanced teaching concept, really take the student as the center, guides them to translate knowledge into business English practical ability.

\section{References}

[1] Zhu H, Lan Y. A Summary of Research on Informatization of Specialized Language in the Framework of Sinoforeign Cooperative Education[J]. Theory and Practice in Language Studies, 2016, 6(9): 1863.

[2] Liu N. Study on the Employment-oriented Professional Training System in Business English Majors[J]. DEStech Transactions on Computer Science and Engineering, 2016 (icte).

[3] Tan J. Research and Analysis on the College English Teaching Emphasis from the Cultural Migration and Transformation of Thinking Perspectives[J]. DEStech Transactions on Social Science, Education and Human Science, 2016 (isetem).

[4] Yinquan W, Wei W, Libing Z. Tentative Thoughts on the Diversified Teaching Modes of College English from the Perspective of Need-based Analysis[J]. Foreign Language Education, 2016, 5: 011.

[5] Xi Y U. The status quo of English teaching in China: An ELF perspective[J]. Foreign Language Learning Theory and Practice, 2016, 3: 006.

[6] Tan X. Language Norm in Various Stages of English Learning in Mainland China[J]. Journal of Studies in Social Sciences, 2016, 14(1).

[7] Gao J, Yu L. Research on the Challenges and Countermeasures of Chinese Language and Literature Education under Teaching Reform Background[J]. DEStech Transactions on Social Science, Education and Human Science, 2016 (isetem).

[8] Koblížková A, Leeming D E. Striving for Higher University World Rankings: The Role of the Language Centre[J]. Linguistics and Literature Studies, 2016, 4(6): 392-401.

[9] Huo C. A Study on The Cultivation of Interdisciplinary \& Application-Oriented Foreign Language Talents Based on Market Demand[J]. Global Journal For Research Analysis, 2016, $5(3)$.

[10] Wang J, Lv Y, Jou M, et al. Research on the effects of cloud-based pedagogy for creative talents: A case study on Chinese High School[J]. Computers in Human Behavior, 2016, 63: 229-239.

[11] Jingzi D, Wenzhong Z, Dimond E E. The integration of intercultural business communication training and business English teaching[J]. English Language Teaching, 2016, 9(2): 77. 
[12] Du J. Think about the English Teaching in Higher Vocational Education[J]. DEStech Transactions on Social Science, Education and Human Science, 2016 (isetem).

[13] Lai M Y. Local Talents Development in Manufacturing Industry by Foreign Company in Vietnam-Example of Taiwanese Firms[J]. 2016.

[14] Qian P. Research on College English Teaching Mode based on Task-based Teaching Method and Flip the Classroom Mode[J]. DEStech Transactions on Social Science, Education and Human Science, 2016 (isetem).

[15] Lokkesmoe K J, Kuchinke K P, Ardichvili A. Developing cross-cultural awareness through foreign immersion programs: Implications of university study abroad research for global competency development[J]. European Journal of Training and Development, 2016, 40(3): 155-170.

[16] Shen P. Research on the New Modern English Teaching Mode in Higher Vocational Colleges based on Multimedia and Interactive System[J]. DEStech Transactions on Social Science, Education and Human Science, 2016 (isetem). 